\title{
Synthesis and ion selectivity studies of potential fluorescent heavy metal ion indicators
}

\author{
George K. Tsikalas, Aggeliki Karavassili, Penelope Lazarou, Philippa Ioanna, \\ and Haralambos E. Katerinopoulos* \\ Division of Organic Chemistry, Department of Chemistry, University of Crete, \\ Heraklion 71003, Crete, Greece \\ E-mail: kater@chemistry.uoc.gr
}

Contribution to the special issue for Prof. Michael Orfanopoulos's $67^{\text {th }}$ birthday

DOI: http://dx.doi.org/10.3998/ark.5550190.p009.063

\begin{abstract}
Two new potential heavy metal ion indicators of the phenanthroline-based family, displaying distinct fluorescence profiles, were synthesized. Their ion selectivity is discussed in terms of their ionophore/fluorophore properties and the extent of conjugation in their framework. The 2(2-hydroxyphenyl)benzazole containing fluorophores used in the construction of the probes, exhibit a unique fluorescence profile with a high Stokes shift that is attributed to an excited state intramolecular proton transfer (ESIPT).
\end{abstract}

Keywords: 5-Amino-1,10-phenanthroline, benzothiazole, benzoxazole, Stokes shift, lead ions, fluorescent sensors

\section{Introduction}

Fluorescent sensors are powerful tools, used in the in vitro and/or in vivo monitoring of biologically relevant species such as metal ions, because of the simplicity and high sensitivity of fluorescence spectroscopy. ${ }^{1}$ A typical fluorescent sensor contains a recognition site, in this case the ionophore, linked to a fluorophore which translates the recognition event into a fluorescence signal. ${ }^{2}$ The design of the "small molecule" probes described herein involves the selection of the phenanthroline moiety as ionophore, since this dinitrogen heterocyclic system coordinates efficiently with heavy atom ions. ${ }^{3-7}$

The selection of the fluorophore required more careful consideration: a large Stokes shift is a highly desired characteristic for a fluorescent probe since it permits an efficient separation of the light exciting the matrix and the light dispersed by the sample. ${ }^{8}$ Excited-state intramolecular 
proton transfer (ESIPT) is a reaction that can produce emissive species with sizeable, often by $100 \mathrm{~nm}$ or more, long wavelength shifts on fluorescence spectra. The ESIPT process generally involves a hydroxyl proton transfer to an acceptor in the excited state, resulting in tautomer emission with a large Stokes shift. ${ }^{9}$ 2-(2-Hydroxyphenyl)benzazoles are handy fluorescent molecules which show high Stokes shifts owing to this mechanism (Scheme 1).

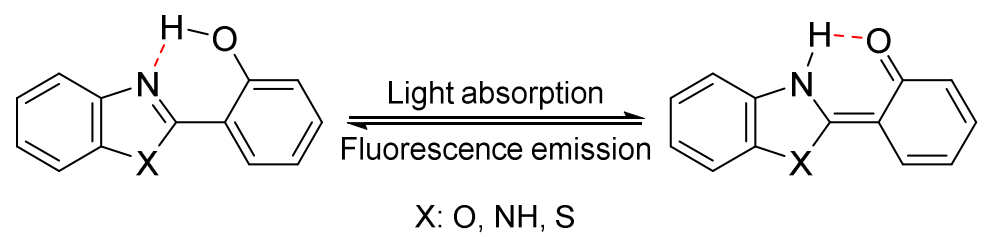

Scheme 1. Prototautomers involved in excited-state intramolecular proton transfer (ESIPT).

\section{Results and Discussion}

4-Amino-2-(benzothiazol-2-yl)phenol (3a) and 4-amino-2-(benzoxazol-2-yl)phenol (3b) were prepared by heating 5-aminosalicylic acid (2) with 2-aminothiophenol (1a) or 2-aminophenol (1b), respectively, in the presence of polyphosphoric acid as described in the literarure. ${ }^{10-12}$ The amines were converted into the respective isothiocyanates $\mathbf{4 a}$ and $\mathbf{4 b}$ by treatment with excess thiophosgene in acetone at ambient temperature. Sensors $\mathbf{5}$ and $\mathbf{6}$ were prepared by mixing the isothiocyanates with 5-amino-1,10-phenanthroline in DMF in the presence of catalytic amounts of 4-diisopropylethylamine (Scheme 2).

Fluorescence studies on sensor 6 in the presence of increasing $\mathrm{Pb}^{2+}$ concentrations revealed the profile of a photoinduced electron transfer (PET) indicator with a distinct "turn on" response in low micromolar $\mathrm{Pb}^{2+}$ ion levels, with a large Stokes shift of $170 \mathrm{~nm}$ (Figure 1). Similar responses have been reported previously by our group ${ }^{13}$ and others, ${ }^{10}$ and are interpreted based on the analogous 2-(2-benzoxazolyl)- and 2-(2-benzothiazolyl)phenol systems that undergo an intramolecular proton transfer at the excited state (ESIPT). This is a very fast (picosecond) mechanism, faster than that of the electron transfer, and is dictated by a tautomeric equilibrium that yields the ESIPT product upon excitation. ${ }^{14-19}$

This effect is responsible for the observed high Stokes shift. Upon excitation of the ion-free probe 6 an electron is transferred from the phenanthroline moiety to the fluorophore and fluorescence is quenched. At micromolar concentrations, the $\mathrm{Pb}^{2+}$ ions coordinate with the nitrogen atoms of the phenanthroline system preventing the electron transfer, thus leading to a "turn on" response mode of the sensor 6 to the presence of $\mathrm{Pb}^{2+}$ ions. The quantum yield of the sensor 6 was calculated as $\Phi=0.045$ that increased to $\Phi=0.11$ at saturating $\mathrm{Pb}^{2+}$ ion concentrations. $^{20-22}$ 
<smiles>[Y][Y10]#[W]</smiles>

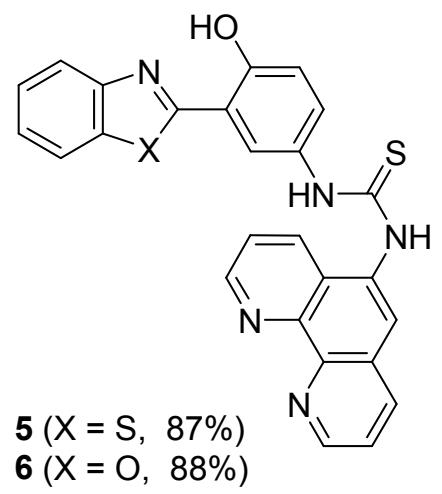

i) $\mathrm{PPA}, 200^{\circ} \mathrm{C}, 4 \mathrm{~h}$ ii) $\mathrm{H}_{2} \mathrm{O}$ iii) $\mathrm{Na}_{2} \mathrm{CO}_{3}$<smiles>[Y][R4](=O)[O-]</smiles>

$\mathrm{CSCl}_{2}$ acetone, rt, $3 \mathrm{~h}$

5-Amino-1,10-phenanthroline DMF, DIPEA, rt, $6 \mathrm{~h}$

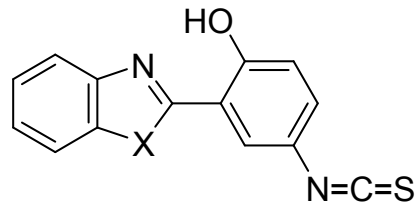

$4 a(X=S)$

4b $(X=0)$

Scheme 2. Synthesis of fluorescent heavy metal sensors $\mathbf{5}$ and $\mathbf{6}$.

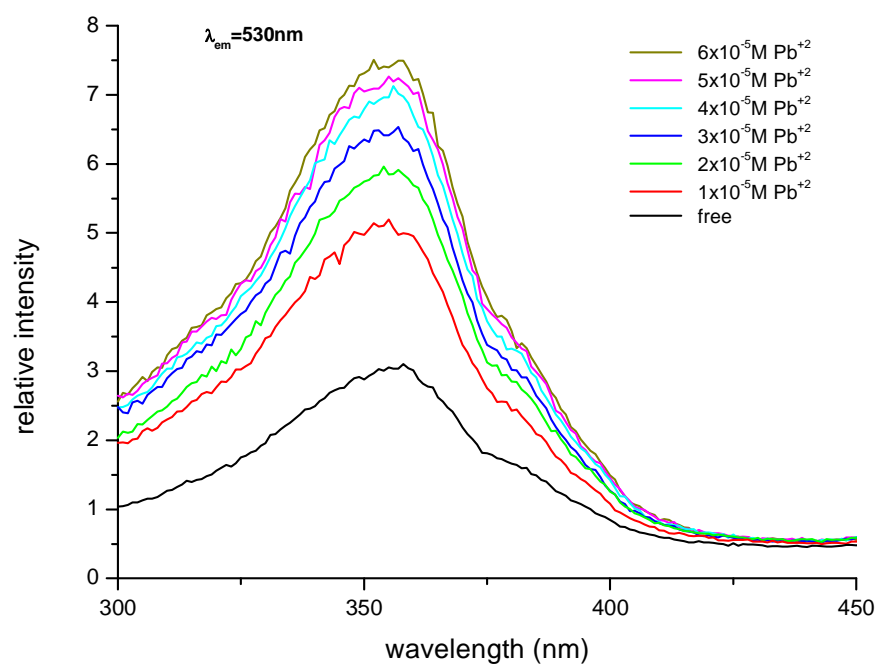




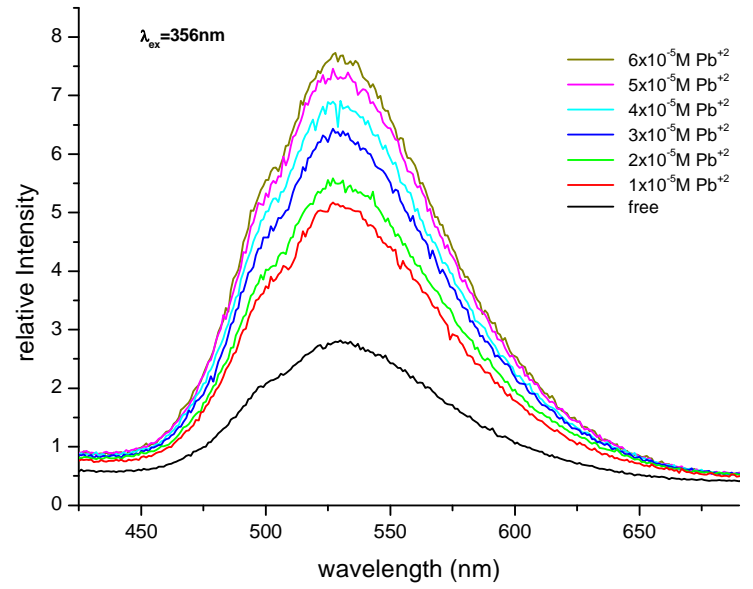

Figure 1. Excitation (top) and emission spectra (bottom) of sensor $6(5 \mu \mathrm{M})$ in nanopure water, $\mathrm{pH}$ adjusted at 7.0, at millimolar $\mathrm{Pb}^{2+}$ ion concentrations. Excitation set at $356 \mathrm{~nm}$, emission maxima detected at $530 \mathrm{~nm}$.

Binding of sensor 6 to a host of metal ions including $\mathrm{Cd}^{2+}, \mathrm{Cu}^{2+}, \mathrm{Fe}^{3+}, \mathrm{Hg}^{2+}, \mathrm{Mg}^{2+}$ and $\mathrm{Mn}^{2+}$ was registered by strong fluorescence quenching. This "turn off" spectral response is known for phenanthroline-type probes such as Phen Green FL and Phen Green SK. ${ }^{4}$ The only exception was that of $\mathrm{Al}^{3+}$ interaction that resulted in a fluorescence decrease at $540 \mathrm{~nm}$ with a simultaneous increase at $450 \mathrm{~nm}$ and a clear isoemissive point at $480 \mathrm{~nm}$. A possible explanation of this behavior is that the $\mathrm{Al}^{3+}$ ions would coordinate with the phenolic oxygen influencing the chromophore and therefore cancelling the ESIPT mechanism. Owing to this effect, a blue shift in the emission spectrum was observed, the Stokes shift decreasing from 185 to $95 \mathrm{~nm}$. This effect is shown on Figure 2 depicting a ratiometric-type fluorescence response of the sensor $\mathbf{6}$ at high micromolar $\mathrm{Al}^{3+}$ ion concentrations.

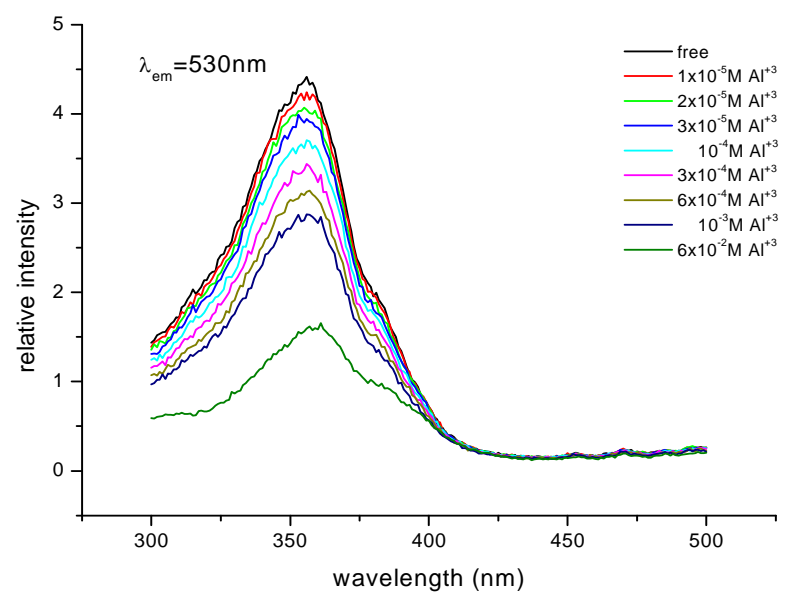




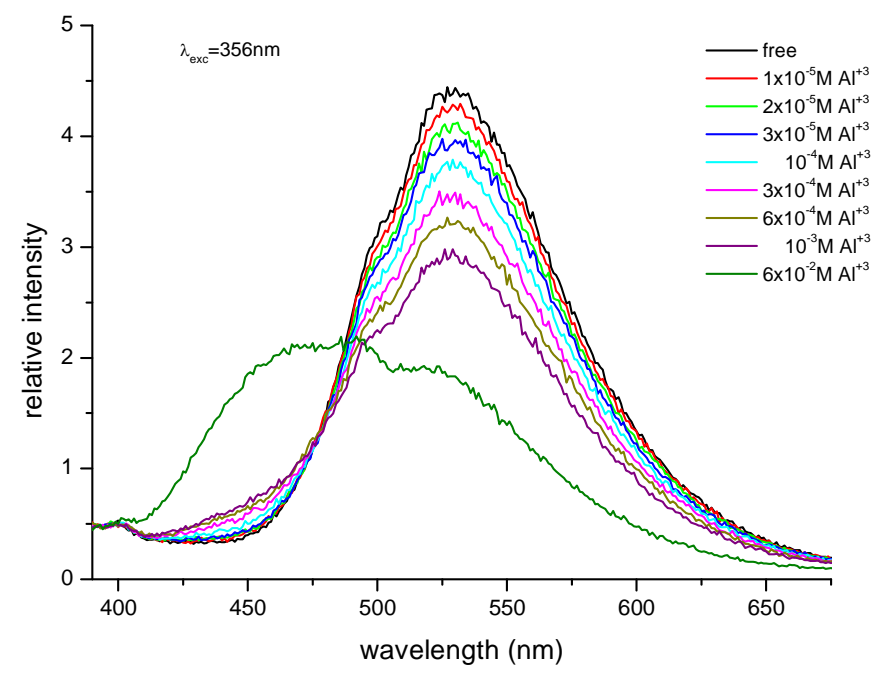

Figure 2. Excitation (top) and emission spectra (bottom) of the sensor $6(5 \mu \mathrm{M})$ in nanopure water, $\mathrm{pH}$ adjusted at 7.0 at millimolar $\mathrm{Al}^{3+}$ ion concentrations. Excitation set at $356 \mathrm{~nm}$, emission maxima detected at $530 \mathrm{~nm}$.

Table 1. Spectral profile of sensors 5 and $\mathbf{6}$ in the presence of increasing ion concentrations

\begin{tabular}{ccccccccc}
\hline Sensor & \multicolumn{3}{c}{$\mathbf{5}$} & & \multicolumn{3}{c}{$\mathbf{6}$} \\
\hline $\begin{array}{c}\lambda_{\text {exc }} \\
(\mathrm{nm})\end{array}$ & $\begin{array}{c}\lambda_{\mathrm{em}} \\
(\mathrm{nm})\end{array}$ & $\begin{array}{c}K_{\mathrm{d}} \\
(\mu \mathrm{M})^{a}\end{array}$ & Response & $\begin{array}{c}\lambda_{\text {exc }} \\
(\mathrm{nm})\end{array}$ & $\begin{array}{c}\lambda_{\mathrm{em}} \\
(\mathrm{nm})\end{array}$ & $\begin{array}{c}K_{\mathrm{d}} \\
(\mu \mathrm{M})^{a}\end{array}$ & Response \\
\hline Ion & & & & & & & & \\
$\mathrm{Pb}^{2+}$ & 360 & 554 & $\mathrm{nd}^{b}$ & Turn off & 356 & 530 & 13.13 & Turn on \\
$\mathrm{Cd}^{2+}$ & 360 & 554 & $\mathrm{nd}^{b}$ & Turn off & 356 & 530 & $\mathrm{nd}^{b}$ & Turn off \\
$\mathrm{Cu}^{2+}$ & 360 & 554 & $\mathrm{nd}^{b}$ & Turn off & 356 & 530 & $\mathrm{nd}^{b}$ & Turn off \\
$\mathrm{Fe}^{3+}$ & 360 & 554 & 118.76 & Turn off & 356 & 530 & 24.65 & Turn off \\
$\mathrm{Fe}^{2+}$ & 360 & 554 & $\mathrm{nd}^{b}$ & Turn off & 356 & 530 & $\mathrm{nd}^{b}$ & Turn off \\
$\mathrm{Hg}^{2+}$ & 360 & 554 & 4.66 & Turn off & 356 & 530 & $\mathrm{nd}^{b}$ & Turn off \\
$\mathrm{Mg}^{2+}$ & 360 & 554 & 7.12 & Turn off & 356 & 530 & $\mathrm{nd}^{b}$ & Turn off \\
$\mathrm{Mn}^{2+}$ & 360 & 554 & $\mathrm{nd}^{b}$ & Turn off & 356 & 530 & $\mathrm{nd}^{b}$ & Turn off \\
$\mathrm{Co}^{2+}$ & 360 & 554 & $\mathrm{nd}^{b}$ & Turn off & 356 & 530 & $\mathrm{nd}^{b}$ & Turn off \\
$\mathrm{Ni}^{2+}$ & 360 & 554 & $\mathrm{nd}^{b}$ & Turn off & 356 & 530 & $\mathrm{nd}^{b}$ & Turn off \\
$\mathrm{Al}^{3+}$ & 360 & 554 & $\mathrm{nd}^{b}$ & Turn off & 356 & $540 / 450$ & 580.45 & Ratiometric \\
\hline
\end{tabular}

${ }^{a} K_{\mathrm{d}}$ values were detected in cases where the decrease in emission intensity of sensors 5 or $\mathbf{6}$ in the presence of increasing ion concentrations was distinct. ${ }^{b} \mathrm{nd}=$ not detected. 
The fluorescence behavior of sensor 5 to a host of ions including $\mathrm{Pb}^{2+}, \mathrm{Cd}^{2+}, \mathrm{Cu}^{2+}, \mathrm{Fe}^{3+}, \mathrm{Fe}^{2+}$, $\mathrm{Hg}^{2+}, \mathrm{Mg}^{2+}, \mathrm{Mn}^{2+}, \mathrm{Co}^{2+}$ and $\mathrm{Al}^{3+}$ is presented on Table 1. The response of the sensor was in all cases a "turn off" one, with dissociation constants in the micromolar range. The ion-free probe exhibits a $\lambda_{\text {exc }}$ maximum of $360 \mathrm{~nm}$ with a respective $\lambda_{\mathrm{em}}$ at $554 \mathrm{~nm}$ and a quantum yield of $\Phi=0.025$. Given the structural similarity of sensors $\mathbf{5}$ and $\mathbf{6}$, the large (194 nm) Stokes shift of the former sensor is, as expected, the result of the ESIPT mechanism.

\section{Metal-ion response screening for ion probes 5 and 6}

A graphical overview of the relative responses of the two sensors to $30 \mu \mathrm{M}$ metal ion solutions is depicted in Figure 3. The results are plotted as fluorescence changes relative to those of the ionfree reference solutions of sensors $\mathbf{5}$ or $\mathbf{6}$, expressed as $(\mathrm{F}-\mathrm{Fo}) / \mathrm{Fo}$, where $\mathrm{F}$ is the fluorescence intensity of ion-containing solutions and Fo is the fluorescence intensity of each reference solution. Blue bars indicate the response to $30 \mu \mathrm{M}$ ion concentration.

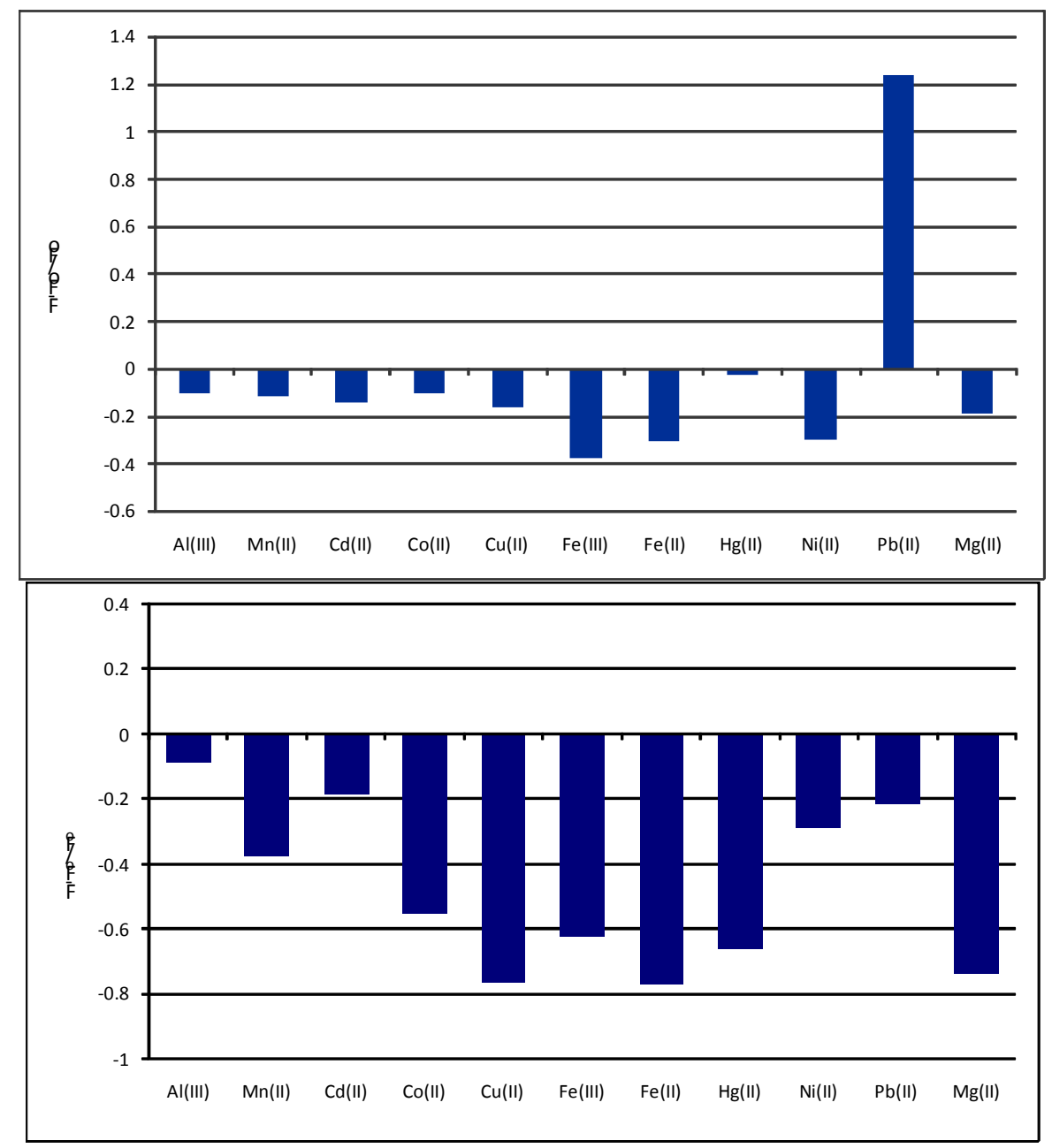

Figure 3. Fluorescence response of sensor $\mathbf{6}$ (top) and $\mathbf{5}$ (bottom) to $30 \mu \mathrm{M}$ metal ion solutions. Results are shown as bar diagrams and are expressed as $(\mathrm{F}-\mathrm{Fo}) / \mathrm{Fo}$, where $\mathrm{F}$ is the fluorescence 
intensity of ion-containing solutions and Fo is the fluorescence intensity of each reference solution.

Worth noticing is the "turn-on" type of response of sensor $\mathbf{6}$ in the presence of $\mathrm{Pb}^{2+}$ ions as opposed to the rest of the ions studied, a behavior that is not observed in the case of sensor $\mathbf{5}$. This difference in response should rest in the inherent properties of both sensors. $\mathrm{Pb}^{2+}$ is a "soft" metal ion and would favor a stronger coordination with the "soft" sulfur atom in the benzothiazole moiety in sensor $\mathbf{5}$, whereas a weaker interaction of $\mathrm{Pb}^{2+}$ with the "hard" oxygen in sensor 6 is expected. It is therefore, possible that the stronger interaction of $\mathrm{Pb}^{2+}$ with the sulfur ion in sensor 5 would result in a decrease in binding with the phenanthroline nitrogens attenuating its interference with the electron transfer process. Moreover, the availability of either heteroatom is retained even upon excitation of the compounds as shown in Scheme 3. This selectivity towards the $\mathrm{Pb}^{2+}$ ions in phenanthroline probes where $\mathrm{O}$-donor atoms are replaced by other softer donor atoms such as $\mathrm{S}$ and $\mathrm{N}$ is well known. ${ }^{23,24}$
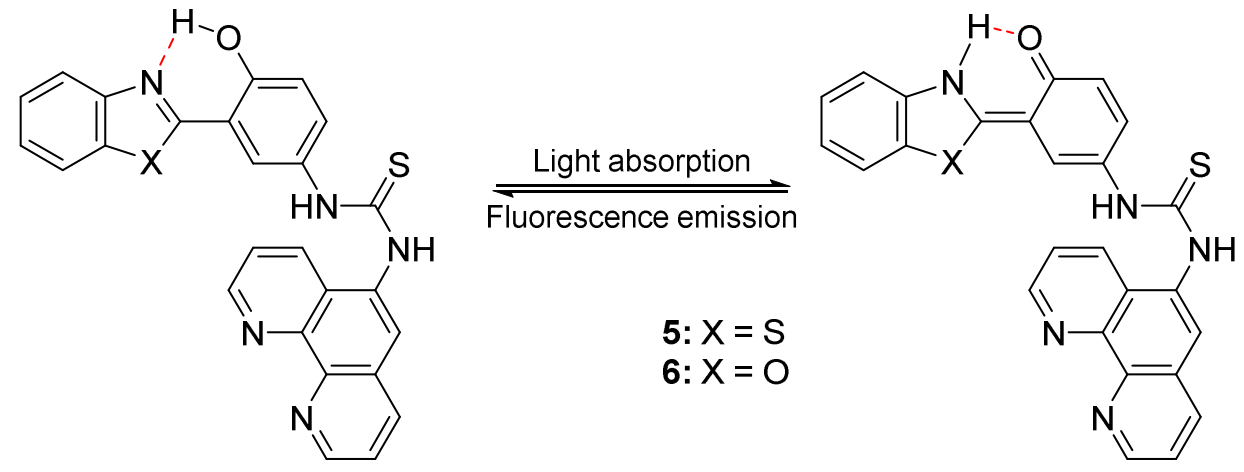

Scheme 3. Prototautomers involved in excited-state intramolecular proton transfer (ESIPT) of compounds 5 or $\mathbf{6}$. Structural changes that take place upon excitation do not alter the availability of heteroatom $\mathrm{X}$ for metal ion coordination.

\section{Conclusions}

Two new small-molecule sensors were prepared via short and efficient syntheses. The benzoxazole-phenanthroline type probe 6 exhibited a "turn-on" behavior selectively for $\mathrm{Pb}^{2+}$ ions and a ratiometric profile response to $\mathrm{Al}^{3+}$ ions; the latter response however, takes place at 45-fold higher concentrations. The response of probe $\mathbf{6}$ to the rest of metal ions studied is a "turn off" one with relatively smaller responses, thus rendering $\mathbf{6}$ a potential lead ion sensor in aqueous solutions. The benzothiazole congener 5 was a "turn off" probe responding to the presence of metal ions with up to $80 \%$ decrease in fluorescence intensity, with $\mathrm{Cu}^{2+}, \mathrm{Fe}^{3+}, \mathrm{Fe}^{2+}, \mathrm{Hg}^{2+}$, and $\mathrm{Mg}^{2+}$ inducing the largest responses. All studies were performed in aqueous solutions, a fact 
implying that both sensors may be practical tools in analytical measurements and the detection of ions in biological studies.

\section{Experimental Section}

General. All reactions were carried out under anhydrous conditions in dry solvents, using argon or nitrogen in flame-dried glassware. Reactions were monitored by thin-layer chromatography (TLC) using silica gel plates from Merck $\left(60 \mathrm{~F}_{254}\right)$, which were visualized under a UV-vis Lamp (254 and $366 \mathrm{~nm}$, respectively) or with a 7\% ethanolic solution of phosphomolybdic acid. Flash column chromatography was performed in silica gel 60 from Merck (230-400 mesh). The Attenuated Total Reflection (ATR)-FTIR spectra were recorded on a Thermo-Electron Nicolet 6700 FTIR optical spectrometer with a DTGS KBr detector at a resolution of $4 \mathrm{~cm}^{-1}$. NMR spectra were taken on an AMX500 Bruker FT-NMR or a MSL300 Bruker FT-NMR spectrometer; proton chemical shifts are reported in relative to tetramethylsilane. Fluorescence spectra were recorded on an Aminco Bowman spectrofluorimeter (Spectronics Co., USA). HRMS were taken at ProFI, Foundation for Research and Technology-Hellas (ITE), Heraklion, Greece. Ultra-pure water was collected from a PURELAB Ultra instrument by ELGA.

4-Amino-2-(benzothiazol-2-yl)phenol (3a) and 4-amino-2-(benzoxazol-2-yl)phenol (3b). Prepared by heating 5-aminosalicylic acid (2) with 2-aminothiophenol (1a) or 2-aminophenol (1b), respectively, in the presence of polyphosphoric acid as described in the literarure. ${ }^{10-12}$

2-(1,3-Benzothiazol-2-yl)-4-isothiocyanatophenol (4a). To a solution of the aminophenol 3a $(245 \mathrm{mg}, 1.01 \mathrm{mmol})$ in acetone $(10 \mathrm{~mL})$ was added dropwise over a 10 min period a 5-fold excess of thiophosgene $(0.390 \mathrm{~mL}, 5.05 \mathrm{mmol})$. The mixture was stirred under argon atmosphere for $2 \mathrm{~h}$ and then the volatiles were removed in vacuo. [Caution: removal of unreacted thiophosgene should take place with great care owing to the toxicity of the reagent.] The yellowish solid product was suspended in cold acetone, filtered and dried under vacuum to afford the title compound $\mathbf{4 a}(280 \mathrm{mg}, 97 \%)$ as a green-grey powder, $\mathrm{mp} 158-159{ }^{\circ} \mathrm{C}$ (not recrystallised). FTIR $\left(\mathrm{cm}^{-1}\right):(\mathrm{N}=\mathrm{C}=\mathrm{S}) 2108 .{ }^{1} \mathrm{H}$ NMR $\left(500 \mathrm{MHz}, \mathrm{CDCl}_{3}\right) \delta_{\mathrm{H}} 9.91(\mathrm{~s}, 1 \mathrm{H}), 8.31(\mathrm{~s}, 1 \mathrm{H}), 8.14(\mathrm{~d}$, $J$ 8.4 Hz, 1H), 8.10 (br.s, 1H), 8.03 (br.s, $1 \mathrm{H}$ ), 7.51-7.45 (m, 1H), 7.44-7.30 (m, 1H), 7.22-7.08 (m, 1H). ${ }^{13} \mathrm{C} \mathrm{NMR}\left(500 \mathrm{MHz}, \mathrm{CDCl}_{3}\right) \delta_{\mathrm{C}} 162.4,155.6,151.3,135.1,133.0,129.5,126.7,125.6$, $125.4,122.5,122.2,121.8,119.9,118.4$. HRMS (ESI) calc for $\mathrm{C}_{14} \mathrm{H}_{9} \mathrm{~N}_{2} \mathrm{OS}_{2} \mathrm{~m} / \mathrm{z}\left(\mathrm{MH}^{+}\right)$ 285.0150 , obsd 285.0181 .

2-(1,3-Benzoxazol-2-yl)-4-isothiocyanatophenol (4b). Prepared following the same procedure described for $4 \mathbf{a}$ starting with aminophenol $\mathbf{3 b}(226 \mathrm{mg}, 1.0 \mathrm{mmol})$ and thiophosgene $(0.390 \mathrm{~mL}$, $5.05 \mathrm{mmol}$ ) in acetone $(10 \mathrm{~mL})$. Yields of the title compound $\mathbf{4 b}$ ranged from 249 to $255 \mathrm{mg}$ (9395\%) of a yellow powder, mp 159-161 ${ }^{\circ} \mathrm{C}$ (not recrystallised). FTIR $\left(\mathrm{cm}^{-1}\right)$ : $(\mathrm{N}=\mathrm{C}=\mathrm{S}) 2114 .{ }^{1} \mathrm{H}$ NMR (500 MHz, $\left.\mathrm{CDCl}_{3}\right) \delta_{\mathrm{H}} 11.61$ (br.s, $1 \mathrm{H}, \mathrm{D}_{2} \mathrm{O}$ exchangeable), $7.90(\mathrm{~d}, J 2.5 \mathrm{~Hz}, 1 \mathrm{H}), 7.77-$ $7.75(\mathrm{~m}, 1 \mathrm{H}), 7.66-7.64(\mathrm{~m}, 1 \mathrm{H}), 7.45,(\mathrm{dd}, J 7.5,5.5 \mathrm{~Hz}, 1 \mathrm{H}), 7.42$ (dd, $J 7.5,5.5 \mathrm{~Hz}, 1 \mathrm{H}), 7.31$ 
$(\mathrm{dd}, J$ 8.5, $2.5 \mathrm{~Hz} 1 \mathrm{H}), 7.10(\mathrm{~d}, J 8.5 \mathrm{~Hz}, 1 \mathrm{H}) .{ }^{13} \mathrm{C} \mathrm{NMR}\left(500 \mathrm{MHz}, \mathrm{CDCl}_{3}\right) \delta_{\mathrm{C}} 161.3,157.5$, 149.1, 148.7, 139.6, 130.6, 126.0, 125.4, 124.0, 123.0, 119.5, 118.8, 111.6, 110.9. HRMS (ESI) calc for $\mathrm{C}_{14} \mathrm{H}_{9} \mathrm{~N}_{2} \mathrm{O}_{2} \mathrm{~S} \mathrm{~m} / z\left(\mathrm{MH}^{+}\right) 269.0379$, obsd 269.0407 .

$N$-[3-(1,3-Benzothiazol-2-yl)-4-hydroxyphenyl]- $N^{\prime}$-[1,10]phenanthrolin-5-yl-thiourea (5). In a flame-dried $50 \mathrm{~mL}$ round bottomed flask were placed DMF $(8 \mathrm{~mL})$ and the isocyanate $4 \mathbf{a}$ (142.0 mg, $5.0 \mathrm{mmol}$ ) followed by 5-amino-1,10-phenanthroline (97.0 mg, $0.5 \mathrm{mmol})$. The mixture was then stirred in the dark, under an argon atmosphere for $2 \mathrm{~h}$. The solution was then diluted with water $(10 \mathrm{~mL})$ and the $\mathrm{pH}$ was adjusted to 7.5 by dropwise addition of $1 \mathrm{~N} \mathrm{HCl}$ solution. The precipitate $(207 \mathrm{mg})$ was filtered and washed with water $(15 \mathrm{~mL})$ then with $\mathrm{Et}_{2} \mathrm{O}$ $(15 \mathrm{~mL})$. The crude product was repeatedly suspended in $\mathrm{Et}_{2} \mathrm{O}$ and then centrifuged to remove traces of side products and yielded the title compound $\mathbf{5}$ (94 mg, 40\%) as a green grey powder, mp 164-165 ${ }^{\circ} \mathrm{C}$ (not recrystallised). FTIR $\left(\mathrm{cm}^{-1}\right):(\mathrm{C}=\mathrm{S}) 1574 .{ }^{1} \mathrm{H}$ NMR (500 MHz, DMSO- $\left.d_{6}\right)$ 10.89 (br.s, 1H), 9.26 (d, $J 4.0 \mathrm{~Hz}, 1 \mathrm{H}), 9.20$ (d, J 4.0 Hz, 1H), 9.04 (dd, J 10.5, 9.0 Hz, 2H), 8.85 (br.s, 2H), 8.47 (s, 1H), 8.35 (d, J 2.0 Hz, 1H), 8.19-8.15 (m, 2H), 8.09 (d, J 8.0 Hz, 1H), $8.01(\mathrm{~d}, J 8.0 \mathrm{~Hz}, 1 \mathrm{H}), 7.59$ (dd, $J$ 8.5, $2.0 \mathrm{~Hz}, 1 \mathrm{H}), 7.49$ (dd, $J$ 7.5, 7.5 Hz, 1H), 7,39 (dd, J 7.5, $7.0 \mathrm{~Hz}, 1 \mathrm{H}), 7.13(\mathrm{~d}, J 8.5 \mathrm{~Hz}, 1 \mathrm{H}) .{ }^{13} \mathrm{C}$ NMR $\left(500 \mathrm{MHz}, \mathrm{DMSO}-d_{6}\right) \delta_{\mathrm{C}} 181.9,164.7,153.8$, 151.4, 148.6, 146.5, 141.9, 138.9, 136.7, 136.6, 135.2, 134.6, 131.2, 129.3, 129.2, 127.7, 126.4, $125.5,125.2,125.00,124.1,123.5,122.1,122.00,118.2,116.9$. HRMS (ESI) calc for $\mathrm{C}_{26} \mathrm{H}_{18} \mathrm{~N}_{5} \mathrm{OS}_{2} \mathrm{~m} / z\left(\mathrm{MH}^{+}\right) 480.0947$, obsd 480.0909 .

$N$-[3-(1,3-Benzoxazol-2-yl)-4-hydroxyphenyl]- $N$ '-[1,10]phenanthrolin-5-yl-thiourea (6). To a solution of the isocyanate $4 \mathbf{b}(134 \mathrm{mg}, 0.5 \mathrm{mmol})$ in dry DMF $(8 \mathrm{~mL})$, was added 5-amino-1,10phenanthroline $(97.0 \mathrm{mg}, 0.5 \mathrm{mmol})$. The system was stirred in the dark, under an argon atmosphere for $2 \mathrm{~h}$. After the completion of the reaction, as indicated by TLC (50\% EtOAc in petroleum ether), the solution was then diluted with water $(10 \mathrm{~mL})$ and the $\mathrm{pH}$ adjusted to 7.5 by dropwise addition of $1 \mathrm{~N} \mathrm{HCl}$ solution. The precipitate was filtered and washed with water (15 $\mathrm{mL}$ ) then with $\mathrm{Et}_{2} \mathrm{O}(15 \mathrm{~mL})$. The crude product $(204 \mathrm{mg})$ was repeatedly suspended in $\mathrm{Et}_{2} \mathrm{O}$ and then centrifuged to remove traces of side products to afford the title compound 6 ( $95 \mathrm{mg}, 41 \%$ ) as a yellow powder, mp $169-170{ }^{\circ} \mathrm{C}$ (not recrystallised) slightly soluble in DMSO at high dilutions. FTIR $\left(\mathrm{cm}^{-1}\right)$ : $(\mathrm{C}=\mathrm{S}) 1522 .{ }^{1} \mathrm{H}$ NMR $\left(500 \mathrm{MHz}, \mathrm{DMSO}-d_{6}\right) 9.90$ (br.s, $\left.1 \mathrm{H}\right), 9.18$ (dd, $J$ 15.0, 3.5 Hz, 1H), 9.02 (br.d, $J 16.5 \mathrm{~Hz}, 1 \mathrm{H}$ ), 8.84 (dd, $J$ 16.5, $7.0 \mathrm{~Hz}, 1 \mathrm{H}$ ), 8.72 (dd, $J$ 7.5, 7.5 $\mathrm{Hz}, 1 \mathrm{H}), 8.52$ (br.d, J $11.5 \mathrm{~Hz}, 1 \mathrm{H})$ 8.47-8.42 (m, 1H), 8.22-8.11 (m, 1H), 8.05-7.84 (m, 3H), 7.35-7.22 (m, 1H), $7.33(\mathrm{~d}, J 7.5 \mathrm{~Hz}, 1 \mathrm{H})$. HRMS (ESI) calc for $\mathrm{C}_{26} \mathrm{H}_{18} \mathrm{~N}_{5} \mathrm{O}_{2} \mathrm{~S} \mathrm{~m} / \mathrm{z}\left(\mathrm{MH}^{+}\right)$ 464.1175, obsd 464.1219.

\section{Preparation of indicator solutions containing adjusted ion concentrations}

In $3 \mathrm{~mL}$ nanopure water $(\mathrm{pH}=7)$ were added $15 \mu \mathrm{L}$ aliquots of a $10 \mathrm{mM}$ in DMSO $(\geq 99.5 \%)$ dye solution to make a final indicator concentration of $5 \mu \mathrm{M}$. To this solution were added microliter aliquots of metal ion stock $10^{-2} \mathrm{M}$ solutions to yield a set of broad ion concentration range dye solutions. 


\section{Acknowledgements}

This work was co-funded by the project "Scholarships SSF-IKY" by means of the European Programme "Education and Lifelong Learning" ESF, NSRF 2007-2013. We are also thankful to the ProFI (Proteomics Facility at IMBB-FORTH) for performing all the HRMS analyses.

\section{References}

1. Tsien, R. Y. In Fluorescent and Photochemical Probes of Dynamic Biochemical Signals Inside Living Cells, Czarnik, A. W. Ed.; American Chemical Society: Washington, DC, 1993, p. 130.

2. De Silva, A. P.; Gunaratne, H. Q. N.; Gunnlaugsson, T. ; Huxley, A. J. M.; McCoy, C. P.; Rademacher, J. T.; Rice, T. E. Chem. Rev. 1997, 97, 1515.

http://dx.doi.org/10.1021/cr960386p

3. Cheng, F.; Tang, N.; Miao, K.; Wang, F. Z. Anorg. Allg. Chem. 2014, 640, 1816. For additional recent publications see references 4-6.

4. Zhang, P.; Pei, L.; Chen, Y.; Xu, W.; Lin, Q.; Wang, J.; Wu, J.; Shen, Y.; Ji, L.; Chao, H. Chem. -Eur. J. 2013, 19, 15494.

http://dx.doi.org/10.1002/chem.201302919

5. Núñez, C.; Silva López, C.; Faza, O. N.; Fernandez-Lodeiro, J.; Diniz, M.; Bastida, R.; Capelo, J. L.; Lodeiro, C. J. Biol. Inorg. Chem. 2013, 18, 679.

http://dx.doi.org/10.1007/s00775-013-1013-5

6. Zheng, Z.-B.; Duan, Z.-M.; Ma, Y.-Y.; Wang, K.-Z. Inorg. Chem. 2013, 52, 2306. For a recent review see reference 7 .

7. Hancock, R. D. Chem. Soc. Rev. 2013, 42, 1500. http://dx.doi.org/10.1039/c2cs35224a

8. Haugland, R. P. The Handbook of Fluorescent Probes and Research Chemicals, Ninth ed., Molecular Probes, Eugene, 2002

9. Demchenko, A. P. J. Fluoresc. 2010, 20, 1099. http://dx.doi.org/10.1007/s10895-010-0644-y

10. Holler, M. G.; Campo, L. F.; Brandelli, A.; Stefani,V. J. Photochem. Photobiol. A. Chem. 2002, 149, 217. http://dx.doi.org/10.1016/S1010-6030(02)00008-4

11. Santos, R. C. D.; Faleiro, N. V. D. S.; Campo, L. F.; Scroferneker, M. L.; Corbellini, V. A.; Rodembusch, F. S.; Stefani, V. Tetrahedron Lett. 2011, 52, 3048.

http://dx.doi.org/10.1016/j.tetlet.2011.04.026

12. Rodembusch, F. S.; Leusin, F. P.; Bordignon, L. B.; Gallas, M. R.; Stefani, V. J. Photochem. Photobiol. A: Chem. 2005, 173, 81.

http://dx.doi.org/10.1016/j.jphotochem.2005.01.006 
13. Tsikalas, G. K.; Lazarou; P.; Klontzas, E.; Pergantis, S. A.; Spanopoulos, I.; Trikalitis, P. N.; Froudakis, G. E.; Katerinopoulos, H. E. RSC Adv. 2014, 4, 693. http://dx.doi.org/10.1039/c3ra45796f

14. Wu, J.; Liu, W.; Ge, J.; Zhang, H.; Whang, P. Chem. Soc. Rev. 2011, 40, 3483. For more recent publications see references 13-17.

15. Chen, S.; Hou, P.; Wang, J.; Song, X. RSC Adv. 2012, $2,10869$. http://dx.doi.org/10.1039/c2ra21471g

16. Xu, Z.; Xu, L.; Zhou, J.; Xu, Y.; Zhu, W.; Qian, X. Chem. Commun. 2012, 48, 10871. http://dx.doi.org/10.1039/c2cc36141h

17. Ma, J.; Zhao, J.; Yang, P. Huang, D.; Zhang, C.; Li, Q. Chem. Commun. 2012, 48, 9720. http://dx.doi.org/10.1039/c2cc35210a

18. Padalkar, V. S.; Tathe, A.; Gupta, V. D.; Patil, V. S.; Phatangare, K.; Sekar, N. J. Fluoresc. 2012, 22, 311. http://dx.doi.org/10.1021/ol2011693

19. Santra, M.; Roy, B.; Ahn, K. H. Org. Lett. 2011, 13, 3422. http://dx.doi.org/10.1021/ol2011693

20. Reported quantum yields are based on quinine sulfate, $\Phi=0.57$ in $0.1 \mathrm{M} \mathrm{H}_{2} \mathrm{SO}_{4}$. For relevant literature see references 19-20.

21. Melhuish, W. H. J. Phys. Chem. 1961, 65, 229. http://dx.doi.org/10.1021/j100820a009

22. Rohwer, L. S.; Martin, J. E. J. Luminesc. 2005, 115, 77. http://dx.doi.org/10.1016/j.jlumin.2005.01.013

23. Li, M.-J.; Ko, C.-C.; Duan, G.-P.; Zhu, N.; Yam, V. W.-W. Organometallics 2007, 26, 6091. For a recent review on the subject see reference 22.

24. Bencini, A.; Lippolis, V. Coord. Chem. Rev. 2010, 254, 2096. 